\title{
Foreign Direct Investment in Nigeria for Promoting Poverty Reduction: Taking the Right Lessons and Avoiding the Wrong Lessons
}

\author{
Attamah, Nicholas, Ph.D *, Kalu Chris U. Ph.D ** \\ * Department of Economics, Enugu State University of Science and Technology, Enugu, Nigeria \\ ** Department of Economics, Nnamdi Azikiwe University, Awka, Nigeria \\ DOI: 10.29322/IJSRP.10.08.2020.p104116 \\ http://dx.doi.org/10.29322/IJSRP.10.08.2020.p104116
}

\begin{abstract}
FDI has undeniably been instrumental in the restructuring, transformation and diversification processes for poverty reduction in many developing countries of the world. However, this has not been the case with the Nigerian economy. This paper examined foreign direct investment for poverty reduction in Nigeria, taking into cognizance the right policy lessons and the avoidable policy scenarios. Using quarterly data sourced from the Central Bank of Nigeria(CBN) Statistical Bulletin, the National Bureau of Statistics and the World Bank Development Indicator (2019) from $1970 \mathrm{Q}_{1}$ to $2018 \mathrm{Q}_{4}$. This paper employed the Dynamic Autoregressive Distributed Lag (ARDL) econometric approach on foreign direct investment, trade liberalization, exchange rate, inflation, interest rate and political stability variables. The choice of these variables are in consonance with the objective of the paper. The findings revealed that economic growth variable showed a negative result in the first lag but positive in the second phase, while exchange rate was positive but insignificant throughout the reviewing periods. Inflation rate was expectedly negative while political stability (proxy for democracy) was expectedly positive. Interest rate was positive but insignificant. The policy implications of these findings on FDI attraction vis-à-vis poverty reduction were discussed. This paper therefore recommended that the Nigerian policymakers should strengthen the macroeconomic reforms to ensure stability, transparency for accountability and growthinvestment stimulating for FDI attraction and for policy reduction. Deepening and enduring the democratic process is also necessary for ensuring veritable investment climate in Nigeria
\end{abstract}

Index Terms- Foreign direct investment, macroeconomic reforms, economic diversification, poverty reduction, Autoregressive distributed lag, Nigeria,

\section{INTRODUCTION}

$F^{a}$ oreign direct investment (FDI) is one of the measures of globalization and it's a wide spread phenomenon which is closely related to the process of economic integration. FDI from the perspective of the Balance of Payments and the International Investment Position share a common conceptual framework given by the International Monetary Fund (IMF). According to the IMF and Organization for Economic Cooperation and Development(OECD), direct investment shows the aim of obtaining a lasting interest by a resident entity of one economy (direct investors) in an enterprise that is resident in another country (the direct investment enterprise).

FDI is the sum of equity capital, reinvestment of earnings, other long-term capital, and short-term capital as shown in the balance of payments. Aggregate FDI flows and stocks generally include all financial transfers aimed at financing new investments, in addition to retained earnings of affiliates, internal loans, and financing of cross-border mergers and acquisitions (Moghalu, 2013). The accepted threshold for a foreign direct investment relationship, as defined by the OECD, is 10 per cent. In other words, the foreign investor must own at least 10 per cent or more of the voting stocks or ordinary shares of the investee company.

On the issues of the terms direct investors and direct investment enterprises, the IMF and OECD define them as follows: A direct investor may be an individual, an incorporated or unincorporated private or public enterprises, a government, a group of related individuals, or a group of related and/or unincorporated enterprises which have a direct investment enterprise, operating in a country other than the country of residence of the direct investor. A direct investment enterprise is an incorporated or unincorporated enterprise in which a foreign. Direct investment enterprises may be subsidies, associates or branches. A subsidiary is an incorporated enterprise in which the foreign investor controls directly or indirectly (through another subsidiary) more than $50 \%$ of the shareholders' voting power. An associate is an enterprise where the director investor and its subsidiaries control between $10 \%$ and $50 \%$ of the voting right. A branch is a wholly or jointly owned unincorporated enterprise. The international economics literature distinguishes typically between horizontal and vertical strategies to identify the benefits of firms with plants in several countries. Horizontal strategies rests on a firms' desire to access a foreign market by replicating production activities abroad. Vertical strategies involve the fragmentation of the supply chain to place production stages using a factor relatively intensively in locations that are well endowed with it. The conglomerate or diversifying strategy is seldom mentioned although in a "non-horizontal" strategy (Hijzenetal, 2008; Coedacier et al.,2009). 
According to the United Nations Conference on Trade and Development (UNCTAD) Reports for 2018 and 2019, total foreign investment into Africa slumped to \$42 billion in 2017, a 21 per cent decline from 2016. Weak oil prices and harmful lingering effects from the commodity bust saw flows contract, especially in the larger commodity-exporting economies. FDI inflows to diversified exporters, including Ethiopia and Morocco, were relatively more resilient. FDI to West Africa fell by 11 per cent to $\$ 11.3$ billion, due to Nigeria's economy depressed. FDI to Nigeria fell 21 per cent to $\$ 3.5$ billion. The FDI inflow into Nigeria has mainly been in the primary sector due to the availability of natural resources from crude oil mostly. This has attracted large amount of multinational oil companies and service/telecommunication operators into the country. FDI inflow into the manufacturing sector and real sectors has not been significant.

FDI inflows into Africa defied the global downwards in 2018. They rose to $\$ 46$ billion, an 11 per cent increase after successive declines in 2016 and 2017. Rising prices of and demand for some commodities led to sustained resource-seeking investment. A few economies, such as Kenya, Morocco and Tunisia made significant recovery after several years of low-level inflows. In contrast, investment in some of the other large recipients, including Nigeria, Egypt and Ethiopia, declined in 2018. However, the expected acceleration of economic growth in Africa, progress towards the implementation of the African Continental Free Trade Area (AfCFTA) and the possibility of some large greenfield investment inflows could drive higher FDI to Africa and Nigeria in particular. Preceding signing into the AfCFTA, the Nigerian government over the years has adopted policies to attract FDI. Some of these policies are: Indigenization programme, the industrialization policy (import substitution and export promotion), the Structural Adjustment Programme (SAP), exchange rate policy, the National Economic and Empowerment Development Strategy (NEEDs/LEEDs), the Transformation Agenda and the Economic Recovery Growth Plan (ERGP). Institutionally, the Nigerian Investment Promotion Council was also established to promote and attract FDI into Nigeria. The objectives of this paper are to:

$$
\begin{aligned}
& \text { discuss the potential effects of FDI on poverty } \\
& \text { reduction } \\
& \text { highlight some of the key drivers of FDI in Nigeria } \\
& \text { empirically estimate the relationship between FDI and } \\
& \text { the key drivers, so as to give empirical validation to } \\
& \text { this paper. }
\end{aligned}
$$

\subsection{Foreign Direct Investment and Poverty Reduction}

FDI's influences on poverty reduction is through two transmission mechanisms-direct and indirect channels. The indirect channel works through FDI's contribution to economic growth given the increasingly role of economic growth in poverty reduction (World Bank, 2000/2001; IFC, 2000; Dollar \& Kraay, 2001a). Furthermore, FDI contributes to tax income of the government budget and may thus promote government sponsored programmes for the poor (Klein et al., 2000). FDI may also induce host governments to invest in infrastructure. It may also raise total capital formation. FDI crowd in domestic investment through backward and forward linkages thereby pushing economic growth.

FDI's direct channel on poverty reduction is through providing opportunities, particularly providing jobs and training to local workers. FDI contributes to reducing existing unemployment and underemployment, providing people with income and therefore directly contributing to poverty reduction (Chudnovsky \& Lopez, 1999; Saravanamutto, 1999). FDI's effect on unemployment relates in part to employment created within direct employment but also to employment created in related entities vertically and horizontally or indirect employment (UNCTAD, 1994). In the same vein, FDI raises unemployment when it is a merger- andacquisition(M\&A) activity. This follows the fact that $M \& A$ activities are fully followed by restructuring the merged enterprise in accordance with the objectives underlying the M\&A (UNCTAD, 1999).

Notwithstanding these roles of FDI on poverty reduction, it is of interest to note that the level of development of the host country plays a major role in determining the degree to which the benefit of FDI are tapped for poverty reduction (Meyer \& Sinani, 2009). The level of economic progress determines the ability of the country to provide local firms that are capable of deriving benefits from the entry of FDI, the necessary skilled labour force, and the ability of the host country to formulate FDI policies that help in poverty reduction. It is worthy of note, that differences in the level of economic development results in a wide margin between the benefits derived from FDI in poor and rich countries (Kemeny, 2009). The effect of foreign direct investment is strong in low income countries with high levels of social capabilities include a supportive institutional framework, effective communication, a well-educated labour force, and infrastructure support (Kemeny, 2010). Figure 1 show poverty rates in Nigeria from 1980 to 2019 . The trend showed that poverty rates have been on the increase in Nigeria over the period, from 40 percent in 1980 to almost 70 per cent in 2019. Outside the disruptions in the stability of the macroeconomic fundamentals, unfavourable investment climate which deter foreign investment and FDI could account for the increase in the poverty rates in Nigeria. 
Figure1: Trend of Poverty Dynamic in Nigeria, 1980- 2019.



Source: CBN Statistical Bulletin (2019)

Figure 2 shows the Gini index and poverty rates of Nigeria from the period 1980 to 2018. The Gini index indicates the distribution of income in an economy over a period of time. In ideal situation, the coefficient will be equal to zero when income is perfectly distributed. The trend showed that both the Gini index and the poverty rates of Nigeria is moving in the same direction. As poverty rate is increasing, the Gini index is also increasing. This implies that income is imperfectly distributed in Nigeria. This no doubt has severe consequences on household income and poverty reduction (Kalu \& Imoagwu, 2020)

Figure 2: Trend of Gini Index and Poverty Rates in Nigeria, 1980-2018 


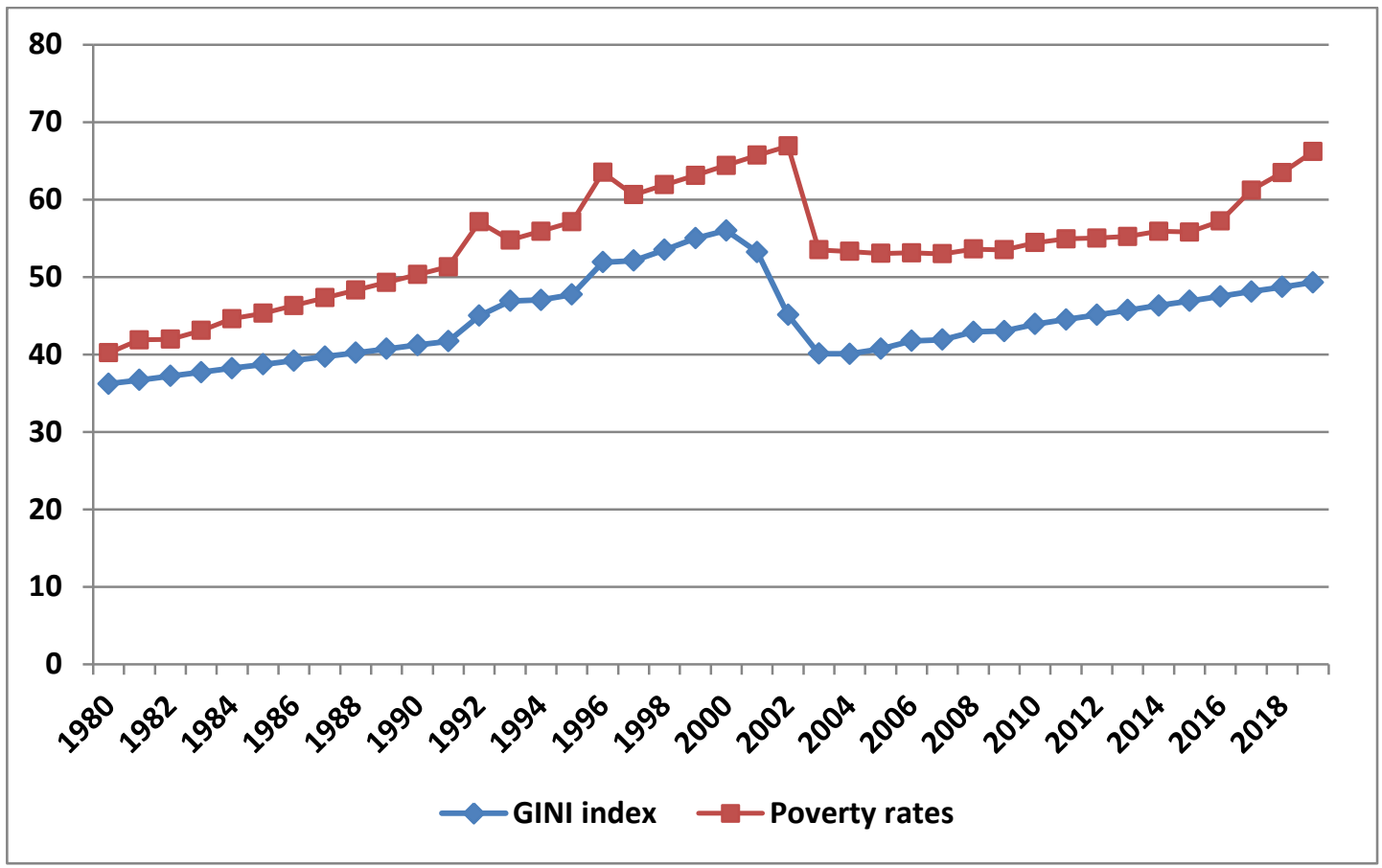

\section{Source: CBN Statistical Bulletin (2019)}

Figure 3 shows the trend of Gini index, poverty rates and unemployment rates in Nigeria from the period 1980 to 2018 . The trend showed that Gini index rose from 38 percent in 1980 to 40 percent in 2018 while the unemployment rate rose from 2 per cent in 1980 to 35 per cent in 2018. The trend further revealed that the gap between Gini index, poverty rates and unemployment rate is of wider margin. The implication of the wider margin could be that inequality in income distribution resulting from unemployment of the labour is the driving force behind the rising poverty rate in Nigeria.

Figure 3: Trend of Gini Index, Poverty Rates and Unemployment Rates in Nigeria, 1980-2018

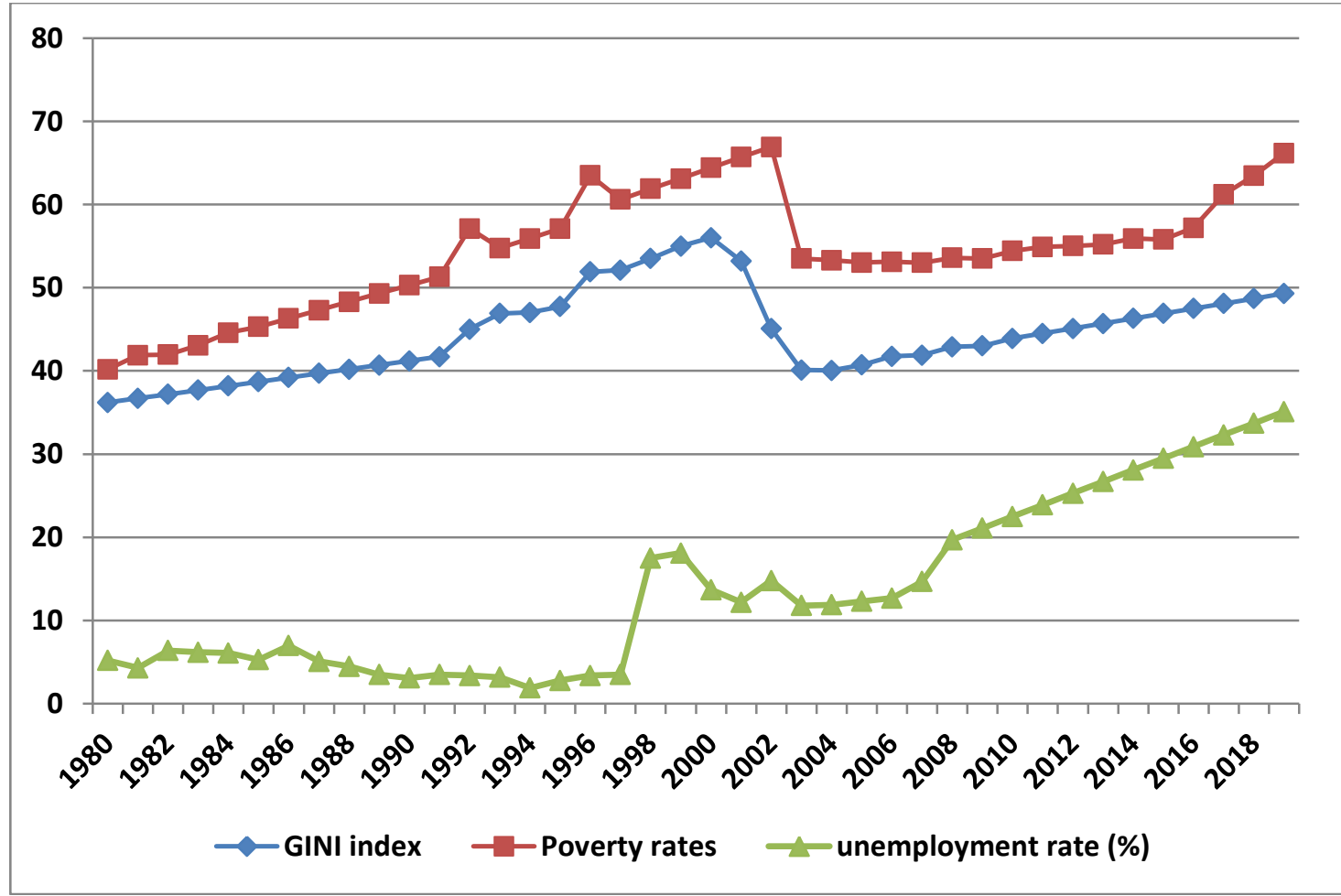

Source: CBN Statistical Bulletin (2019)

This publication is licensed under Creative Commons Attribution CC BY. 


\section{LITERATURE REVIEW: POTENTIAL EFFECTS OF FOREIGN DIRECT INVESTMENT (FDI)}

\section{a) FDI Boosts International Trade}

FDI boost international trade. Several empirical studies have examined the relationship between international trade and FDI. Clausing (2000) uses panel data approach to examine the relationship not only US outward FDI and exports but also between US and inward FDI and import from 1977 to 1994. The research finds that both inward and outward FDI will boost trade. Zhang and Li (2007) also studied the effect of inward FDI flows on total trade volume of China based on panel data with 14 investing countries from 1990 to 2004. A positive relationship was found in their study. Similarly, Rafiq and Yun (2017) concluded that FDI brings innovative technology and bring value added phenomena to domestic tradable merchandize. Qayyum and Mahood (2013) investigated the causality between FDI and foreign trade for Pakistan and its eight major trading partners for yearly data from 1985 to 2010, using the complementary approaches: vector error correction model and Johansen Fisher panel co-integration.

\section{b) FDI Reduces Local Tension}

In a study, Kolstad and Tondel (2002) finds that FDI flows are affected by ethnic tension, internal conflict, and democracy, but not by government stability, bureaucracy, external conflict, law and order and the military been involved in politics. Corroborating Kolstad and Tondel (2002) , Busse and Hefeker (2007) find that government stability, internal and external conflicts, corruption, ethnic tensions, law and order , democratic accountability of government and quality of bureaucracy are highly significant determinants of FDI inflow. Although, there are contrary views on the negative effect of conflicts on FDI inflow (Wheeler and Mody, 1992; Noorbaksh et al.,2001; Asiedu, 2002). FDI attraction no doubt reduces local tension when attracted into a country.

\section{c) FDI Promotes Economic Diversification}

No country has experienced sustained growth and significant reduction in poverty without integrating into the global economy. Banga (2003) have argued that FDI can foster the growth of the exportation base through the spillover effects on the level of export of the home growth firms who are involved in the traditional export sector. This spillover effect generated from the fact that the export of foreign firms in this sector lowers the fixed cost of introducing the sector's product in the foreign market. In addition to lowering the fixed cost, the home firms may also learn and gain experience from the foreign firms and become knowledgeable about the existence of new markets and openings in the foreign market. These no doubt promote the export diversification base of the home country (Rhee, 1990).

\section{d) FDI Promotes Employment and Economic Growth}

A country needs stable and productive investment inflows to ensure sustainable growth and employment creation. Effect of a rise in FDI on employment could be differentiated between greenfield and brownfield investments (Dafaux, 2010). However, brownfield investment is not used to establish a new company, it is used for merger and acquisitions., when greenfield investment is concerned, the impact on employment is positive. However, it has a negative effect on the short-run. There are direct and indirect effects on employment associated with FDI flows to host country. Mostly in the countries where capital is relatively scarce due to negligible domestic saving opportunity, the new employment prospects have been one of the most significant impacts of FDI (Kurtishi- Kastrati, 2013). The direct effect of foreign ownership may have either positive or negative effect. Indirect effect indicates the spillover generated by the activities of foreign owned companies that are expected to affect productivity of incumbent foreign owned firms and domestic firms or in the host country.

\section{e) FDI Promotes Tax Incentives and Tax Holidays}

Most governments use tax incentives and holidays to attract a certain types of investment rather than to change their aggregate level. Oman (2001) revealed that several foreign companies- such as the automotive sector-are in a better position to negotiate special tax regimes and thus attain income from host government. Tax holidays are a common form of tax incentives used by developing countries to attract FDI. The newly established companies are not required to pay tax for a certain period of time (e.g. five years) to encourage investment. FDI promotes the establishment of tax incentive by the host in order to attract FDI into the country.

\section{d) FDI and Reduction of Poverty}

Hung (1999) analyzed the relationship between FDI and poverty reduction between 1992 and 2002 in a sample of 12 provinces and cities in Vietnam. Using poverty incidence as a measure of poverty, and using panel data, the paper found FDI to reduce poverty. Hung (1999) found that a $1 \%$ increase in FDI reduced the number of people living in poverty by $0.05 \%$. This direct effect of FDI on poverty reduction was found to be higher than indirect effect through GDP growth.

Jalilian and Weiss (2008) investigated the effect of FDI on poverty reduction on the ASEAN countries during the period 1999 to 2007, using unbalanced panel data and the income of the bottom $20 \%$ of the population as the poverty measure. Fowowe and Shuaibu (2014) investigated the effect of FDI on the poor in a sample of 30 African countries, using pooled data from 1981 to 2011. The World Bank poverty headcount was used as a proxy for poverty. Based on the Generalized Methods of Moments(GMM), they found FDI to be good for the poor. In a similar paper, Bharadwaji (2014) studied the effect of FDI on poverty in 35 developing countries from 1990 to 2004. In the paper, FDI was used as a proxy for globalization, while the headcount ratio and poverty gap were used to measure poverty. Using a panel regression, Baradwaji (2014) found FDI to be negatively related to the headcount ratio. FDI was found to be beneficial to poverty reduction in the sample countries. On the contrary, Tsai and Hung (2007), Akinmulegan (2012), Gohou and Soumare(2012) and Oguniyi and Igberi(2014) found insignificant effect of FDI on poverty reduction. 


\section{DRIVERS OF FOREIGN DIRECT INVESTMENT: REASONS FOR ITS LOW ATTRACTION IN NIGERIA}

Some of the factors that determine a country's attraction of foreign direct investment in relation to its macroeconomic fundamentals, and influencing of sustainable growth and development includes:

(a) Rate of Inflation: Incessant oscillation in the general price level (inflation) reflects unstable macroeconomic environment in an economy, resulting to increased perceived risk in in investment. This further leads to negative impact on FDI inflow. Moreover, when the rate of inflation is high, the real returns on investment reduces (see Schneider\& Frey, 1985; Trevino \& Mixon, 2004; Tripathi et al. 2015). Keeping the rate of inflation down calls for responsible fiscal policies that avoid persistent shocks. It also requires a disciplined approach to monetary policy, including selfdenial in resorting to domestic borrowing from monetary authorities. The persistent high rate of inflation in Nigeria is shock to economy that scares FDI inflows into the Nigerian economy

(b) Exchange Rate: Increase or decrease in the value of currency of host country leads to fall or rise in the exchange rate respectively and thus makes its goods costlier or cheaper for the foreign customers. Thus, the export positive of the country changes in the international markets which further affects the FDI inflows in it. Exchange rate management has implication for private investment. Various empirical studies (Dombush, 1988; Serven 1990; Serven \& Sohinano,1993; Olofin,1999) have shown that real exchange rate depreciation is capable of affecting private investment in at least three ways: i) through the real cost of capital ii) the real interest rate iii) through real output The irrational pricing of the multiple exchange rates, leads to loss of confidence in the domestic currency. The outcome fuels artificial demand for forex not to invest in the economy but to hold in anticipation of further weakening of the naira.

(c) Interest Rate: Interest rate is quite another important macroeconomic factor known to affect savings and investment in an economy. The existing literature established a negative relationship between interest rate in a country and FDI outflows from it. Similarly, interest rate in the host country and FDI inflows in it have a positive relationship. Thus, a higher interest rate in domestic market discourages FDI inflows due to higher returns expectation (Cleyg, 1987; Grubaugh, 1987; Krykilis \& Pantehidis 2003; Lall, 1980, Prugel, 1981). The interest rate spread and high loanable fund rate are scarecrows to FDI attraction in Nigeria

(d) Trade Openness: Trade openness can be explained as the degree of trade flexibility between two trading countries, is the extent to which a country has trade with other foreign nations or economies. It is computed as:

$$
\text { Trade Openness }=\frac{\text { Export }+ \text { Imports }}{G D P} \times 100
$$

Trade openness also play major roles(s) in attracting FDI in a country. Higher trade openness should encourage more FDI inflows and vice versa (see Scaperlanda \& Mauer, 1973; Scaperland \&Balough, 1983; Scaperlanda,1992). The high cost of business registration and ease of doing business in Nigeria is a barrier to FDI establishment in Nigeria.

(e) Heterodox Fiscal and Monetary Policy. Several years of heterodox monetary and fiscal practices have sunk the economy abysmally culminating in the Federal Government begging for foreign direct investment. Macroeconomic policies affect macroeconomic environment which in turn affects FDI inflows through three key transmission channels: i) fiscal deficit financing ii) uncertainty resulting from large fiscal deficits (iii) the complementarity or substitutability between private and public investment financing the fiscal deficit through creating money reduces money balances and puts pressure on interest rates. On the other hand, doing so through financial repression has negative effects. Either way, private investment is reduced, with possible effect on export and economic growth. Alternatively, financing fiscal deficits through increased foreign borrowing also limits economic growth and private investment, as it reduced investors' confidence (Olofin, 1999). When investors' confidence is eroded following ineffective fiscal policy implementation, it has a negative effect on FDI attraction, a scenario common to Nigeria

(f) Policy Creativity and Political Stability: Uncertainties arise when a weak implementation of political will persist. Dombush (1998) and Rodrick (1989) emphasize the importance of investors perception of the government's willingness and ability to implement private sector oriented growth strategy. One major source of uncertainly is the lack in credibility of policy reforms or the fear of policy reversals. Usually private investors either delay investments or do not invest at all in an environment dominated by uncertainties. Basing investment incentive measure on credit, stable and predictable policy measures often has a positive impact on aggregate investment (Jayaraman, 1996).

In relation to the issue of policy reforms is the need for stability in institutions that are aimed at promoting growth and investment. Essentially, these institutions refer to rule, regulatory legal frameworks and social norms governing economic transactions. Foreign investor wants the policies of the country to be stable and transparent to provide enough safeguard for their investments because instability increases the risk to the foreign investor (Drabek \& Payne, 1999).

g) Real Economic Growth: Positive economic growth trend of an economy is also among the channel through which FDI is attracted in the economy. However, the effect of FDI on economic growth has shown to be much compared to that of domestic investment due to transmission of technology. Camurdan and Cevis (2009) reported that inflation rates, the interest rate, the growth rate and the trade openness rate were the main drivers of FDI inflows into an economy. The poor nominal GDP rate expressed in per capita income which is below the standard and the low growth rate of less than 4 percent sometimes in the negative(recession) in Nigeria is a challenge to attracting FDI into Nigeria.

\section{THE MODEL AND DATA}

4.1 The Model

This publication is licensed under Creative Commons Attribution CC BY.

http://dx.doi.org/10.29322/IJSRP.10.08.2020.p104116

www.ijsrp.org 
The econometric approach is based on the dynamic autoregressive distributed lag regressions(ARDL) in an equation for foreign direct investment rate. The specification is in tandem with the dynamic regression literature and allows for the identification of the channels through which macroeconomic aggregates affect FDI over time. The theoretical/mathematical formulation is presented as follows: $\mathrm{FDI}=\left(\mathrm{GDP}_{t}, \operatorname{Trdop}_{t} \mathrm{EXR}_{t}\right.$, $\left.\mathrm{INF}_{\mathrm{t}}, \mathrm{INT}_{\mathrm{t}} \mathrm{POl}_{\mathrm{t}}\right) \quad(4.1)$

Where, FDI is the foreign direct investment variable, the dependent variable; GDP is an explanatory variable, the growth indicator; Trdop, the trade openness variable; EXER, exchange rate; INF, inflation; INT, interest rate and POL, political stability. These exogenous variables have been previously explained in the preceding section as some of the key drivers of FDI. The essence of subjecting these variables in an econometric model is to give empirical validation to the study.

First, the ARDL co-integration approach was developed by Pesaran and Shin (1999) and Pesaran et al. (2001). Its applications have been extensively applied to studies of macroeconomic variables like the variables of the model. It has three seemingly advantages in comparison to the Johansen/conventional methods of estimating co-integration relationships. The first one is that the dynamic analysis does not need that all the variables of interest be integrated of the same order and it can be applied when the under-lying variables are integrated of Order One, I (1), Order zero, I (0) or fractional integrated. The second advantage is that the ARDL test is relatively more efficient in the case of small and finite sample data size. The third is that by applying the techniques of derive unbiased estimate s of the long-rein model (Harns \& Sollis, 2013. Ewun et al. 2015). The ARDL econometric model specifications of the included exogenous variables are expressed hereunder. The ARDL model is specified thus:

$\mathrm{D}\left(\operatorname{In}\left(\mathrm{FDI}_{\mathrm{t}}\right)=\mathrm{a}_{01}+\mathrm{b}_{11} \operatorname{In}\left(\mathrm{FDI}_{\mathrm{t}-1}\right)+\mathrm{b}_{21} \operatorname{In}\left(\mathrm{RGDP}_{\mathrm{t}-1}\right)\right.$ $+b_{31} \operatorname{In}\left(\operatorname{TrdoP}_{\mathrm{t}-1}\right)+\mathrm{b}_{41} \operatorname{In}\left(\mathrm{EXR}_{\mathrm{t}-1}\right)$

$+b_{51} \operatorname{In}\left(\operatorname{InF}_{\mathrm{t}-1}\right)+\mathrm{b}_{61} \operatorname{In}\left(\mathrm{INT}_{\mathrm{t}-1}\right)+\mathrm{b}_{71} \operatorname{In}\left(\mathrm{POL}_{\mathrm{t}-1}\right)$

$+\sum_{i 1}^{p} \mathrm{a}_{1 \mathrm{i}} \mathrm{D}\left(\operatorname{In}\left(\mathrm{FDI}_{\mathrm{t}-1}\right)+\sum_{i 1}^{q} \mathrm{a}_{2 \mathrm{i}} \mathrm{D}\left(\operatorname{In}\left(\mathrm{RGDP}_{\mathrm{t}-1}\right)\right)+\sum_{i 1}^{q} \mathrm{a}_{3 \mathrm{i}}\right.$

$\mathrm{D}\left(\operatorname{In}\left(\operatorname{TrdoP} \mathrm{P}_{\mathrm{t}-1}\right)\right)$



$i \stackrel{1}{q}$

$+\sum \mathrm{a}_{7 \mathrm{i}} \mathrm{D}\left(\operatorname{In}\left(\mathrm{POL}_{\mathrm{t}-1}\right)\right)+\mathfrak{f}_{\mathrm{it}}$

$i 1$

$\mathrm{D}\left(\operatorname{In}\left(\mathrm{RGDP}_{\mathrm{t}}\right)\right)=$

$+b_{32} \operatorname{In}\left(\operatorname{Trdo} P_{t-1}\right)$

$+b_{42} \operatorname{In}\left(E R_{t-1}\right)+b_{52} \operatorname{In}\left(\operatorname{InF}_{t-1}\right)+b_{62} \operatorname{In}\left(\operatorname{Int}_{\mathrm{t}-1}\right)+b_{72} \operatorname{In}\left(\mathrm{POL}_{\mathrm{t}-1}\right)$

$+\sum^{q} \mathrm{a}_{1 \mathrm{i}} \mathrm{D}\left(\operatorname{In}\left(\operatorname{RGDP}_{\mathrm{t}-1}\right)\right)+\stackrel{q}{\sum^{2}} \mathrm{a}_{2 \mathrm{i}} \mathrm{D}\left(\mathrm{FDI}_{\mathrm{t}-1}\right)++\stackrel{q}{\sum} \mathrm{a}_{3 \mathrm{i}} \mathrm{D}\left(\operatorname{In}\left(\operatorname{TrdoP}_{\mathrm{t}-}\right.\right.$

$i 1 \quad i 1 \quad i 1$

1))

$+\sum^{q} \mathrm{a}_{4 \mathrm{i}} \mathrm{D}\left(\operatorname{In}\left(\mathrm{EXR}_{\mathrm{t}-1}\right)\right)+\stackrel{q}{\sum} \mathrm{a}_{5 \mathrm{i}} \mathrm{D}\left(\operatorname{In}\left(\operatorname{InF}_{\mathrm{t}-1}\right)\right)+\stackrel{q}{\sum} \mathrm{a}_{6 \mathrm{i}} \mathrm{D}\left(\operatorname{In}\left(\mathrm{INT}_{-1}\right)\right)$

$i \underset{q}{1}$

$+\sum \mathrm{a}_{7 \mathrm{i}} \mathrm{D}\left(\operatorname{In}\left(\mathrm{POL}_{\mathrm{t}-1}\right)\right)+£_{2 \mathrm{t}}$

$i 1$
$\mathrm{D}\left(\operatorname{In}\left(\operatorname{TrdoP} \mathrm{P}_{\mathrm{t}}\right)\right)=\mathrm{a}_{03}+\mathrm{b}_{13} \operatorname{In}\left(\mathrm{FDI}_{\mathrm{t}-1}\right)+\mathrm{b}_{23} \operatorname{In}\left(\mathrm{RGDP}_{\mathrm{t}-1}\right)$

$+\mathrm{b}_{33} \operatorname{In}\left(\operatorname{TrdoP}_{\mathrm{t}-1}\right)$

$+\mathrm{b}_{43} \operatorname{In}\left(\mathrm{EXR}_{\mathrm{t}-1}\right)+\mathrm{b}_{53} \operatorname{In}\left(\operatorname{InF}_{\mathrm{t}-1}\right)+\mathrm{b}_{63} \operatorname{In}\left(\operatorname{Int}_{\mathrm{t}-1}\right)+\mathrm{b}_{73} \operatorname{In}\left(\mathrm{POL}_{\mathrm{t}-1}\right)$

$\left.\left.\left.+\sum^{q} \mathrm{a}_{1 \mathrm{i}} \mathrm{D}\left(\operatorname{Trdo}_{\mathrm{t}-1}\right)\right)+\mathrm{a}_{2 \mathrm{i}} \mathrm{D}\left(\operatorname{FDI}_{\mathrm{t}-1}\right)\right)+\sum^{q} \mathrm{a}_{3 \mathrm{i}} \mathrm{D}\left(\operatorname{RGDP}_{\mathrm{t}-1}\right)\right)+\sum^{q} \mathrm{a}_{4}$

$i 1 \quad i 1 \quad i 1$

$\left.\mathrm{D}\left(\mathrm{EXR}_{\mathrm{t}-1}\right)\right)$

$\left.\left.\left.+\sum_{i 1}^{q} \mathrm{a}_{5 \mathrm{i}} \mathrm{D}\left(\operatorname{InF}_{\mathrm{t}-1}\right)\right)+\sum_{i 1}^{q} \mathrm{a}_{6 \mathrm{i}} \mathrm{D}\left(\mathrm{INT}_{-1}\right)\right)+\sum_{i 1}^{q} \mathrm{a}_{7 \mathrm{i}} \mathrm{D}\left(\mathrm{POL}_{\mathrm{t}-1}\right)\right)+£_{3 \mathrm{t}}$

$\mathrm{D}\left(\operatorname{In}\left(\mathrm{EXR}_{\mathrm{t}}\right)\right)=\mathrm{a}_{04}+\mathrm{b}_{14} \operatorname{In}\left(\mathrm{FDI}_{\mathrm{t}-1}\right)+\mathrm{b}_{24} \operatorname{In}\left(\mathrm{RGDP}_{\mathrm{t}-1}\right)$

$+b_{34} \operatorname{In}\left(\operatorname{TrdoP}_{t-1}\right)$

$\left.+\mathrm{b}_{35} \operatorname{In}\left(\mathrm{POL}_{\mathrm{t}-1}\right) \mathrm{b}_{36} \operatorname{In}\left(\operatorname{InF}_{\mathrm{t}-1}\right)+\mathrm{b}_{44} \operatorname{In}\left(\operatorname{InT}_{\mathrm{t}-1}\right)+\stackrel{q}{\sum^{2}} \mathrm{a}_{1 \mathrm{i}} \mathrm{D}\left(\mathrm{EXR}_{\mathrm{t}-1}\right)\right)$



(4.4)

$\mathrm{D}\left(\operatorname{In}\left(\operatorname{InF}_{\mathrm{t}}\right)\right)=\mathrm{a}_{05}+\mathrm{b}_{15} \operatorname{In}\left(\mathrm{FDI}_{\mathrm{t}-1}\right)+\mathrm{b}_{25} \operatorname{In}\left(\mathrm{RGDP}_{\mathrm{t}-1}\right)$

$+\mathrm{b}_{35} \operatorname{In}\left(\operatorname{TrdoP}_{\mathrm{t}-1}\right)$

$\left.+\mathrm{b}_{36} \operatorname{In}\left(\operatorname{InT}_{\mathrm{t}-1}\right)+\mathrm{b}_{37} \operatorname{In}\left(\mathrm{POL}_{\mathrm{t}-1}\right)+\sum_{i-1}^{q} \mathrm{a}_{1 \mathrm{i}}\left(\operatorname{InF}_{\mathrm{t}-1}\right)+\sum_{i=1}^{q} \mathrm{a}_{21} \mathrm{D}\left(\mathrm{FDI}_{\mathrm{t}-1}\right)\right)$

$+\sum_{\left.\left.\left.i \sum_{q}^{1} \mathrm{a}_{3 \mathrm{i}} \mathrm{D}\left(\mathrm{RGDP}_{\mathrm{t}-1}\right)\right)+\sum_{i 1}^{q} \mathrm{a}_{4 \mathrm{i}} \mathrm{D}\left(\operatorname{TrdoP}_{\mathrm{t}-1}\right)\right)+\sum_{i 1}^{q} \mathrm{a}_{5 \mathrm{i}} \mathrm{D}\left(\operatorname{InF}_{\mathrm{t}-1}\right)\right)}$

$\left.+\sum_{i=1} \mathrm{a}_{6 \mathrm{i}} \mathrm{D}\left(\mathrm{PoL}_{\mathrm{t}-1}\right)\right)+\mathfrak{£}_{5 \mathrm{t}}$

$\mathrm{D}\left(\operatorname{In}\left(\operatorname{Int}_{\mathrm{t}}\right)\right)=\mathrm{a}_{06}+\mathrm{b}_{16} \operatorname{In}\left(\mathrm{FDI}_{\mathrm{t}-1}\right)+\mathrm{b}_{26} \operatorname{In}\left(\mathrm{RGDP}_{\mathrm{t}-1}\right)$

$+\mathrm{b}_{36} \operatorname{In}\left(\operatorname{TrdoP} \mathrm{P}_{\mathrm{t}-1}\right)+\mathrm{b}_{46} \operatorname{In}\left(\operatorname{InT}_{\mathrm{t}-1}\right)$

$+\mathrm{b}_{56}\left(\operatorname{Inf}_{\mathrm{t}-1}\right)+\mathrm{b}_{66} \operatorname{In}\left(\right.$ POL $\left.\left._{\mathrm{t}-1}\right)+\sum_{i 1}^{q} \mathrm{a}_{1 \mathrm{i}}\left(\operatorname{Int}_{\mathrm{t}-1}\right)+\sum_{i 1}^{q} \mathrm{a}_{21} \mathrm{D}\left(\mathrm{FDI}_{\mathrm{t}-1}\right)\right)$

$+\sum^{q} \mathrm{a}_{3 \mathrm{i}}$

$i 1$

$\left.\left.\left.\mathrm{D}\left(\operatorname{RGDP}_{\mathrm{t}-1}\right)\right)+\sum_{i 1}^{q} \mathrm{a}_{4 \mathrm{i}} \mathrm{D}\left(\operatorname{TrdoP}_{\mathrm{t}-1}\right)\right)+\sum_{i 1}^{q} \mathrm{a}_{5 \mathrm{i}} \mathrm{D}\left(\operatorname{Int}_{\mathrm{t}-1}\right)\right)+\sum_{i 1}^{q} \mathrm{a}_{6 \mathrm{i}}$

$\left.\mathrm{D}\left(\mathrm{INF}_{\mathrm{t}-1}\right)\right)$

$\left.+\sum_{i=1}^{q} \mathrm{a}_{7 \mathrm{i}} \mathrm{D}\left(\mathrm{PoL}_{\mathrm{t}-1}\right)\right)+\mathfrak{f}_{6 \mathrm{t}}$

$\mathrm{D}\left(\operatorname{In}\left(\mathrm{Pol}_{\mathrm{t}}\right)\right) \quad=\quad \mathrm{a}_{07}+\mathrm{b}_{17} \operatorname{In}\left(\mathrm{FDI}_{\mathrm{t}-1}\right)+\mathrm{b}_{26} \operatorname{In}\left(\mathrm{RGDP}_{\mathrm{t}-1}\right)$

$+b_{36} \operatorname{In}\left(\operatorname{TrdoP} P_{t-1}\right)$

$+\mathrm{b}_{46} \operatorname{In}\left(\operatorname{Int}_{\mathrm{t}-1}\right)+\mathrm{b}_{56}\left(\operatorname{Inf}_{\mathrm{t}-1}\right)+\mathrm{b}_{66} \operatorname{In}\left(\mathrm{POL}_{\mathrm{t}-1}\right)+\sum_{i=1}^{q} \mathrm{a}_{1 \mathrm{i}}\left(\operatorname{Pol}_{\mathrm{t}-1}\right)+$

$\left.\sum^{q} \mathrm{a}_{21} \mathrm{D}\left(\mathrm{FDI}_{\mathrm{t}-1}\right)\right)$

$i \underset{q}{1} \quad q \quad q$

$\left.\left.\left.+\sum_{i 1} \mathrm{a}_{3 \mathrm{i}} \mathrm{D}\left(\operatorname{RGDP}_{\mathrm{t}-1}\right)\right)+\sum_{i 1} \mathrm{a}_{4 \mathrm{i}} \mathrm{D}\left(\operatorname{TrdoP}_{\mathrm{t}-1}\right)\right)+\sum_{i 1} \mathrm{a}_{5 \mathrm{i}} \mathrm{D}\left(\operatorname{Int}_{\mathrm{t}-1}\right)\right)$

This publication is licensed under Creative Commons Attribution CC BY. 


$$
\left.+\sum_{i=1}^{q} \mathrm{a}_{6 \mathrm{i}} \mathrm{D}\left(\operatorname{InF}_{\mathrm{t}-1}\right)\right)+\mathfrak{£}_{7 \mathrm{t}}
$$

The mode of transmission of these variables on foreign direct flow had already been discussed on section 3. However, it must be emphasized that (Sachs \& Waner, 1997; Degefe, 1999) postulated that an economy is certified as open and liberalized if the following criteria were satisfied: an average tariff rate below 40\%; average quota and licensing coverage of import duty of less than 20\%; no control on export in the form of taxes, quotas and state monopolies are not considered a socialist country. Furthermore, UNCTAD (1999) (173) recognized that without sufficient domestic saving to finance the investment necessary for rapid and sustained economic expansion, it may be difficult to attract FDI. It was on these theoretical premises that our FDI model was specified.

\subsection{The Data}

A quarterly data set for Nigeria from 1970 Q1 to 2015 Q4 was compiled for the purpose of this paper. All data were taken from the Nigeria secondary database pool (CBN Statistical Bulletin and National Bureau of Statistics). This was complemented by the World Bank's World Development Indicator (WDI, 2019). Data were estimated using Econometric View Software (E-View 10.0). Sourcing these data were seriously challenging in terms of reliability and data accuracy, however, the various pre- and post-econometric procedure were to enhance robustness of the data.

\section{EMPIRICAL RESULT AND INTERPRETATIONS}

The first point of call in every time series analysis is to examine the level of integration on otherwise the stationery statistic properties of the estimated variable, and that is done here using the conventional augmented Dickey Fuller (ADF) and Philip-Perron (PP) tests. The essence of conducting the test is to ensure that the variables are not spurious or unfit for policy inference. The ADF/PP results are presented in Table 5.1

Table 5.1: ADF and PP Results

\begin{tabular}{|l|l|l|l|l|}
\hline Variables & $\begin{array}{l}\text { T- } \\
\text { Statistic } \\
\text { (levels) }\end{array}$ & $\begin{array}{l}\text { Critical } \\
\text { value at } \\
\mathbf{5 \%} \text { (diff.) }\end{array}$ & $\begin{array}{l}\text { T-stat } \\
\text { LFDI }\end{array}$ & $\begin{array}{l}\text { Critical } \\
\text { value at } \\
\mathbf{5 \%} .\end{array}$ \\
\hline LGDP & $(0.06448)$ & $\begin{array}{l}-6.5233 * * * \\
(0.0000)\end{array}$ & $\begin{array}{l}-0.8742 \\
(0.7945)\end{array}$ & $\begin{array}{l}-5.3519 * * * \\
(0.0000)\end{array}$ \\
& $-2.26626 *$ & $\begin{array}{l}-6.9196 * * * \\
(0.0000)\end{array}$ & $\begin{array}{l}-2.5251 \\
(0.1112)\end{array}$ & $\begin{array}{l}-6.8320 * * * \\
(0.0000)\end{array}$ \\
& $(0.0826)$ & & & \\
\hline LOPN & -0.1790 & $-6.3070 * * *$ & -0.3947 & $-6.4686 * * *$ \\
& $(0.9375)$ & $(0.0000)$ & $(0.9062)$ & $(0.0000)$ \\
\hline LEXR & -0.4087 & $-6.0722 * * *$ & -0.5883 & $-6.0930 * * *$ \\
& $(0.9039)$ & $(0.0000)$ & $(0.8689)$ & $(0.0000)$ \\
\hline
\end{tabular}

This publication is licensed under Creative Commons Attribution CC BY.

http://dx.doi.org/10.29322/IJSRP.10.08.2020.p104116

\begin{tabular}{|c|c|c|c|c|}
\hline INF & $\begin{array}{l}- \\
2.9057 * * \\
(0.0467)\end{array}$ & $\begin{array}{l}-5.0860 * * * \\
(0.0000)\end{array}$ & $\begin{array}{l}- \\
3.1307 * * \\
(0.0262)\end{array}$ & $\begin{array}{l}-4.1588^{* * * *} \\
(0.0000)\end{array}$ \\
\hline INT & $\begin{array}{l}-1.6975 \\
(0.4308)\end{array}$ & $\begin{array}{l}-4.7657 * * * \\
(0.0000)\end{array}$ & $\begin{array}{l}-1.8583 \\
(0.3514)\end{array}$ & $\begin{array}{l}-3.2619 * * \\
(0.0183)\end{array}$ \\
\hline PSTB & $\begin{array}{l}-0.7591 \\
(0.82720\end{array}$ & $\begin{array}{l} \\
13.4907 * * * \\
(0.0000)\end{array}$ & $\begin{array}{l}-0.7591 \\
(0.8277)\end{array}$ & $\begin{array}{l} \\
13.4907 * * * \\
(0.0000)\end{array}$ \\
\hline
\end{tabular}

Note: $(*)$ significant at the $10 \% ;(* *)$ significant at $5 \% ;(* * *)$ significant at the $1 \%$ values in parathensis () are the probability values

\section{Source: Authors' Computation using EVIEW 10.0}

The result of the stationarity tests show that all variables are non-stationery at levels. However, the first difference of the data series rejects the null hypothesis of non-stationarity for all the variables used in the study. It is therefore, worth mentioning that all the variable was integrated of Order One, 1 (1). Having ascertained the stationery process of the variables, we then went ahead to conduct the ARDL bounds test for co-integration. In essence, the test typically verifies the long-run relationship if there is any and the short-run dynamics (ECN) of interaction among the variables of interest (FDI, RGDP, Tradop, EXER, INF, INT, Pol), following Pesaran and Shin (1999) and Pesaran et al. (2001). The result is presented in Table 5.2

\section{Table 5.2: Results from Bound Test}

\begin{tabular}{|l|l|l|l|}
\hline Dependent variables & K & $\begin{array}{l}\text { F- } \\
\text { statisti } \\
\text { c }\end{array}$ & Decision \\
\hline $\begin{array}{l}\text { FDI(RGDP,Tradop,FXR,INR,INT } \\
\text {,PSTB) }\end{array}$ & 6 & $\begin{array}{l}3.9438 \\
90\end{array}$ & $\begin{array}{l}\text { Contegrati } \\
\text { on }\end{array}$ \\
\hline Lower-bound critical value at 5\% & $\begin{array}{l}2.4 \\
5\end{array}$ & & \\
\hline Upper-bound critical value at 5\% & $\begin{array}{l}3.6 \\
1\end{array}$ & & \\
\hline
\end{tabular}

Source: Authors' Computation using Eview 10.0

From these results, it is clear that there exist some of cointegration (long-run relationship) amongst the variables as evidenced by the F-statistic of (3.943890), which is higher to both the lower-bound (2.45) and the upper-bound (3.61) of the $5 \%$ level of significance. Therefore, this results suggest that the null hypothesis of no co-integration between FDI and the determining variables is rejected. Table 5.3 present the ARDL short-run results.

Table 5.3: ARDL Error Correction Result

\begin{tabular}{|l|l|l|l|l|}
\hline Variables & Coefficient & $\begin{array}{l}\text { Study } \\
\text { Error }\end{array}$ & $\begin{array}{l}\text { T- } \\
\text { Statistic }\end{array}$ & probability \\
\hline$\Delta$ FDI(-1) & 0.616187 & 0.061906 & 9.953543 & 0.0000 \\
\hline$\Delta$ RGDP & 0.389176 & 0.121036 & 3.215377 & 0.0016 \\
\hline
\end{tabular}




\begin{tabular}{|l|l|l|l|l|}
\hline $\begin{array}{l}\Delta \text { RGDP(- } \\
1)\end{array}$ & -0.210975 & 0.120401 & - & 0.0816 \\
\hline$\Delta$ Tradop & 0.136807 & 0.087744 & 1.559157 & 0.1209 \\
\hline$\Delta$ EXER & 0.020146 & 0.024702 & 0.815570 & 0.4159 \\
\hline$\Delta \mathrm{INF}$ & -0.000194 & 0.000692 & - & 0.7796 \\
& & & 0.280328 & \\
\hline$\Delta \mathrm{INT}$ & 0.002036 & 0.003492 & 0.582858 & 0.5608 \\
\hline PSTB & 0.115176 & 0.046224 & 2.491703 & 0.0137 \\
\hline $\begin{array}{l}\text { [Cont.Eq.(- } \\
1)]^{*}\end{array}$ & -0.118285 & 0.024472 & - & 0.0000 \\
\hline
\end{tabular}

Contegration $=[$ FDI-

$(0.1860 *[\mathrm{GDP}+0.052 *[\mathrm{OPEN}+0.1703 *$ LEXR -

$0.0016 * \mathrm{INF}+0.072 * \mathrm{INT}+0.9737 *$ PSTBT 6.611$)$

The major concern here is the outcome of the cointegration as shown on the table, with a value of -0.118285 . Theoretically, the negative significant shows appropriateness of the value and the short-run dynamics. This implies that overall, it takes abysmally 11.8 percent of the disequilibrium technically for the variables and its influencing power to be adjusted or corrected over the period. The long-run result is presented in Table 5.4

Table 5.4: Estimated long-run Coefficients using the ARDL Approach

\begin{tabular}{|c|c|c|c|c|}
\hline Variables & Coefficient & $\begin{array}{l}\text { Study } \\
\text { Error }\end{array}$ & $\begin{array}{l}\text { T- } \\
\text { Statistic }\end{array}$ & probability \\
\hline $\mathrm{C}$ & 1.018627 & 0.282297 & 3.608348 & 0.004 \\
\hline LFDI $(-1)$ & 1.49902 & 0.061916 & 24.19252 & 0.0000 \\
\hline LFDI(-2) & -0.616187 & 0.061906 & -9.953543 & 0.0000 \\
\hline LGDP & 0.389176 & 0.121036 & 3.215377 & 0.0016 \\
\hline LGDP(1) & $-0,578150$ & 0.202502 & -2.855037 & 0.0048 \\
\hline LGDP(-2) & 0.210975 & 0.120401 & 1.752262 & 0.0816 \\
\hline LOPN & 0.136807 & 0.087744 & 1.559157 & 0.1209 \\
\hline LOPN(-1) & -0.137417 & 0.086255 & -1.591312 & 0.1134 \\
\hline LEXR & 0.020146 & 0.024702 & 0.815570 & 0.4159 \\
\hline 'INF & -0.000194 & 0.000682 & -0.280328 & 0.7796 \\
\hline INT & 0.002036 & 0.003492 & 0.582858 & 0.5608 \\
\hline PSTB & 0.115176 & 0.046224 & 2.491703 & 0.0137 \\
\hline \multicolumn{5}{|l|}{ R-Square } \\
\hline \multicolumn{5}{|c|}{$\begin{array}{llll}\text { Var } & 11.90143 & & \\
\text { Adjusted R.Sq. } 0.991211 & \text { S.D. } & \text { dependent } \\
\text { Var } & 1.140720 & & \end{array}$} \\
\hline \multicolumn{2}{|l|}{$\begin{array}{l}\text { F-statistic } \\
2.043568\end{array}$} & 25.894 & \multicolumn{2}{|c|}{ Durbin Watson } \\
\hline
\end{tabular}

Note: P-Values and any subsequent tests do not account for model selection.

Source: Authors Computation using E-VIEW 10.0

Our focus here is to examine how the exogenous or explaining variables affect FDI in Nigeria case, for illustrative purposes. From the estimate results, the long-run GDP value as a determinant of FDI is negative, although significant, while trade liberalization proxy by trade openness in positive and significant while in the long period, it recorded negative although significant. The estimated coefficient of exchange rate although positive is insignificant, while inflation is appropriate signed with negative outcome. Interest rate although positive has little or no value in FDI attraction. while, political stability is both positive and significant in determining FDI inflow over the period. Overall, the explanatory variables accounts for about 99 percent of the changes or variation in the dependent variables of FDI, the adjusted R-Square of 99 percent also corroborated the outcome. The overall relevance of the variables in explaining the changes in the outcome of FDI inflow into Nigeria is positive and significant at the value of 1825.894 with probability value of 0.000000 . The estimated coefficients show no trace of serial disturbance with a Durbin Watson value of 2.043568. The policy implication of the empirical findings is reported in the next section. The Policy Implementation of Findings are as follows:

- Growth and productivity output needs to be improved and sustained over the period

- Much stability and transparency is required in monetary policy managements as a determinant to capital inflow.

- Political stability and credibility through democracy no doubt is a sine qua non for FDI attraction.

\section{2 Discussion of Key Findings}

This section briefly describes the economic and structural consequences leading to the empirical result and that will be done in consonance with the policy implication. From the empirical results the outcomes of growth on FDI is in line with similar findings in literature. While many studies observe positive impacts of FDI on economic growth, others also reported a negative relationship. As noted by (De Mello,1997), two channels have been advanced to explain the positive relationship between FDI and economic growth. First, capital accumulation in the recipient country, FDI is expected to be growth enhancing by encouraging the incorporation of new inputs and foreign technologies in the production function of recipient economy. Second, through transfer technology, FDI is expected to increase the existing stock of knowledge in the recipient economy through labour training and skill acquisition (Borensztein et al. 1998). The positive relationship between FDI and economic positive growth in further lend credence by (Howhury and Mavrotas (2006) who examined the causal relationship between FDI and economic growth by using time series data covering the period 1909-2000 in three developing countries, namely Chile, Malaysia and Thailand. The findings suggest that GDP causes FDI in the case of Chile and not vice versa, while for both Malaysia and Thailand, there is strong evidence of bi-directional casualty between the two variables. From the result also, the first lad of economic growth and FDI was negative. This result is in tandem with Carkovic and Levine (2003) who concluded in their paper that FDI does promote economic growth and vice versa. Furthermore, many other studies in developing countries are mixed on the relationship between FDI and economic growth. In the class of such studies are Blomstrom \& Sjoholm,1999, Aiken et al. 1997. Some of the reasons adduced for these mixed results are that the envisaged forward and background linkages may not necessarily be there and that the arguments of multinationals encouraging non-subSaharan African countries. However, that benefits are realized 
more in non-sub-Saharan African due to greater trade liberalization. This assertion by Asiedu (2002) is in variance with the recent evidence from UNCTAD publican.

The publication reported that FDI inflows to Africa remained flat at $\$ 54$ billion, decreasing in north Africa and rising in sub-Saharan Africa. The report went further to posit that < North Africa saw its FDI flows decline by 15 percent to $\$ 11.5$ billion, while flows to sub-Saharan Africa rose by 5 percent to \$42.4 billion, (UNCTAD 2015:34) Sein (2009) argues that foreign firms that have the objectives to expand their market may resolve that in the face of a high degree of costs; the market could be better served through an export rather than FDI.

Others such as Busse and Hefker (2007) and Globerman and Shapiro (2002) conclude that, there is no statistical significant relationship between FDI and trade openness hence, trade openness has no effect on FDI. However, the results obtained by Goodspeed et al. (2006) turned out to be inclusive with respect to openness.

The result shows that exchange rate coefficient is positive but insignificant at the $5 \%$ level. A result similar to the one obtained by Alaba (2003) and Ogunleye(2008). From Alaba (2003), the official market exchange rate volubility is not significant for FDI inflows to the manufacturing and agricultural sectors while Ogunleye (2011) concluded that the sub-Saharan African countries do not receive the desired FDI because it is constrained by exchange rate volatility. The study by (Jose Fillipe de Sousa Matric,2015) revealed that both in the short -run and long-run, real exchange rate volatility has a statistically significant negative impact on Brazilian FDI inflows.

Inflation impacts negatively on FDI in Nigeria within the reviewing period. However, a study by Anitha (2012) revealed an unexpected positive relationship between foreign direct investment and inflation in the Indian economy. Singh and Gin (2016) have given possible reasons behind the negative relationship between inflation and FDI as Follows: 1) high level of prices in the country resulting in rising production costs II) high prices adversely affecting domestic and foreign demand for commodities II) reduction in business profit IV) foreign reserves. A positive but insignificant relationship was found between interest rate and FDI. A result similar to Faroh and Shen (2015) for Sierra Leone. The no significant impact of interest rate on FDI was further given credence by Chingurande et al. (2012) for the Zimbabwean economy. The relationship between policy stability and FDI was found to be positive and significant in line with the postulation of development theory.

The results also show a positive relationship between political stability and foreign direct investment with the reviewing period. Several empirical reviews have emerged in the literature concerning political and FDI. For example, Jessup (1999) submitted that foreign direct investment increases market shares in authoritarian countries. The main reason of Tessup's argument is based on the difference between democratic and autocratic regimes in executive constraint. FDI would prefer autocratic regimes because of less executive constraint which provides greater foreign direct investment inflows. O'neal (1994) argued that authoritarian regimes economy offers higher returns that democratic regimes economy in developing countries. The author made a differentiation between "Centre" and "Periphery" countries. According to the author, investors achieve higher returns and have higher investment rates in democratic Centre nation but if the nation is "periphery" for Latin American countries, investors changes the preference and autocratic regimes becomes more attractive because of higher returns. Blanton and Blantum (2007) in a paper concluded that there is a significant correlation between human right and FDI, while Olson (1991) emphasizes the importance of property rights on investors and argues that if the authoritarian government is predatory, protection of property rights or getting the principal rights carries high risks. For Olson, with independent guidance's and regular change in elected officials of strong democratic, promotes stronger property rights and so higher levels of democracy should attract more FDI (Olson, 1993; Biglaiser DeRouen 2005; Biglaiser \& Daris, 2002; North, 1995).

From the empirical results, it was found out that the variables (economic growth, trade openness, exchange rate, inflation, interest rate and political stability) explain about 99 percent of the variations in the dependent variables This implies the drivers of FDI in Nigeria within the reviewing period. The Durbin value of 2.043568 shows the lack of serious disturbance of any sort on the model estimates, while the reliability of the estimate was given further authenticity by the empirical reliability check of Breusch-Godfrey Serial Correlation Test with F-statistic value of 0.76903 (p-0.999995).

\section{CONCLUSION AND RECOMMENDATIONS}

This paper examined FDI for poverty reduction in Nigeria within the reviewing period. The empirical analysis was anchored on the dynamic autoregressive distributed lag model (ARDL) approach developed by Pesaran and Shin (1999) and Pesaran et al. (2001). From the empirical results, the economic growth proxy, GDP was found to be positive, but negative is the first lag. Literature posits a positive relationship between economic growth and FDI empirical evidence have proven contrary that negative growth and also influence. The negative outcome of GDP on FDI could be attributed to the slow economic growth in Nigeria over the years. This has been caused by low sector contribution to GDP rate in Nigeria. A situation that has resulted to the recession or decline in growth rate. From the result, trade liberalization was positive but negative in the first lag meaning that in the long-run, the current policies may not help in the attraction of FDI unless there is a change in the dynamics of trade policies to boost inflows. Also, exchange rate was found to be positive but insignificant implying that exchange rate management in Nigeria may not have a serious determinant of FDI in Nigeria. The big gap and the inefficient regulation of the black market window might have been the cause.

On the other hand, inflations appear appropriately signed in line with the literature, implying really that inflation sears FDI, while interest rate and political stability is positively but insignificantly related to FDI in the case of interest rate. In Nigeria, the interest rate margins of 21 percent and above may have actually scared foreign investors, who may also need domestic sources of funding. The democracy in Nigeria and the current economic reforms including the judicial reforms must contribute to the FDI inflows in Nigeria within the review period. The policy makers are therefore presented with the following right lessons: 
Appropriate strategies to boost economic growth and to prevent the economy relapsing into recession in the future. The sectors of the economy needs regeneration through fiscal and monetary stimuli.

ii) Trade liberalization/policy reform should be pursued in line with Sachs and Warner (1997) criteria.

iii) The source and gap between the official exchange rate and the black market needs to be shrink or at least close to zero.

iv) The institutional reforms need to be strengthened and encouraged so as to attract the desired foreign direct investment in Nigeria.

The achievement of these lessons and policy prescriptions and avoidance of the wrong lessons, that FDI can only be achieved when the policymakers throttle the globe begging for business alliances and bilateral and multilateral trade and investment relations and agreements will encourage the attraction of FDI inflows into the Nigerian economy in the new and foreseeable feature. It therefore behooves on the policymakers to re-think on the existing monetary, fiscal and trade policies and making the Nigerian investment policies and environment investor friendly to attract and sustain FDI.

\section{REFERENCES}

[1] Aitken, B., Hanson, G.H., \& Harrison, A.E. (1997) Spillovers foreign direct investment and export behaviour. Journal of International Economics, 43(1):103-132. http://dx.doi.org/10.1016/s0022-1996(96)01464-x.

[2] Akinmulegun, S.O.(2012) Foreign direct investment and standard of living in Nigeria, Journal of Applied Finance and Banking, 2(3): 20-34

[3] Alaba, O. B. (2003). Exchange rate uncertainly and foreign direct investment in Nigeria. Trade Policy Research and Training Programme (TPRTP), university of Ibadan Nigeria.

[4] Aritha, R. (2012) Foreign direct investment and economic growth in India. IRJC International Journal of Marketing, Financial Service \& Management Research, I (8):15-21

[5] Asiedu, E. (2002). On the determinant of foreign direct investment to developing countries in Africa, 1980-2007. Is African different? World Development,30(1):107-119

[6] Banga, R. (2003) Impact of government policies and investment agreements on FDI inflows. Working Paper No.116(November) New Delhi. Indian Council for Research on International Economic Relations.

[7] Bharadwaj, A. (2014) Reviving the globalization and poverty debate: Effects of real and financial integration on the developing world. Advances in Economics and Business 2(1): 15-24

[8] Blomstrom, M. (1986) Foreign investment and productivity efficiency: The case of Mexico. The Journal of Industrial economics,35(1): 97-110. http://dx.doi.org/10.2307/2098609.

[9] Blomstrom, M., \& Sjoholm, F. (1999) Technology transfer and Spillover: does local participation with multinational matters? European Economic Review, 43(4):915-923. http://dx.doi.org/10.1016/s0014-2921(98)00104-4.

[10] Borensztein, E.(1998) How does foreign investment affect economic growth? NBER Working Paper No. 5057

[11] Borensztein, E., De Gregorio, J., \& Lee, J.W. (1998) How does foreign direct investment affect economic growth? Journal of International Economics. 45(1):115-135. http://dx.doi.org/10.1016/s00221996(97)00033-0.

[12] Busse, M. Hefker, Co (200\&) Political risk institutes and foreign direct investment. European Journal of Political Economy 23397-415

[13] Carkovic, M. V., \& Levine, R. (2002) Does foreign direct investment accelerate economic growth? University of Minnesota Department of Finance Working Paper. http://dx.doi.org/10.2139/ssm.314928.

[14] Chingarande, A. (et al. (20120 the Impact of interest rates on foreign direct investment. A Case study of the Zimbabwean economy, (February 2009-
June 2011). International Journal of management Sciences and Business Research 1(5):1-24.

[15] Chowdhury, A., \& Mavrotas, G. (2006) FDI and growth: what causes what? The World Economy, 29(1):9-19. http://dx.doi.org/10.1111/j.14679701.2006.00755.x.

[16] Chudnovsky, D. \& Lopez, A. (1999) Globalization and developing countries: Foreign direct investment and growth and sustainable human development UNCTAD Occasional Paper

[17] Clausing, K.A.(2000) Does multinational activity displace trade? Economic Inquiry, 38(2):190-215

[18] Coeurdacier, N., De Santis, R.A \& Aviat, A.(2009) Cross-border mergers and acquisitions and European integration. Economic Policy, 57:56-106

[19] De Mello Jr, L.R. (1997) Foreign direct investment in developing countries and growth: A Selective Survey. The Journal of Development Studies, 34(1): 1-34. http://dx.doi.org/10.1080/00220389708422501.

[20] Dollar, D. \& Kraay, A.(2001a) Growth is good for the poor. Policy Research Working Paper 2587, World Bank, Washington DC.

[21] Faroh, A. \&Shen, H. (2015) Impact of interest rates on foreign direct investment. Case Study Sierra Leone economy.

[22] Fowowe, B., \& Shuaibu, M.I.(2014) Is foreign direct investment good for the poor? New evidence from African countries. Economic Change Restructuring 47: 321-339.

[23] Globalman, S. \& Shapiro, D. (2002) Global foreign direct investment flows: The Role of governance infrastructure. World Development 30(ii):18991919.

[24] Goodspeed, T. Torge, M-v \& Li, Z. (200\&). Are government policies more important than taxation in attraction FDI? International Studies Programs Working Paper, no 07-02 (2007), Andrew Young School of policy studies, Georgia State University.

[25] Gohou, G \& Soumare, I.(2012) Does foreign direct investment reduces poverty in Africa and are there regional differences? World Development, 40: 75-95

[26] Jose F., \& de Sousa M. (2015) Impact of real exchange rate volatility on foreign direct investment inflows in Brazil. Project submitted as partial requirement for the conferral of M.sc in finance, Institute Universityrio de Lisboa.

[27] Hijzenetal, A., Gorg, H. \& Manchin, M. (2008) Cross- border mergers and acquisitions and the role of trade costs, European Economic Review 52:849-866

[28] Hung, T.T.(1999/2005) Impacts of foreign direct investment on poverty reduction in Vietnam. Discussion Paper. National Graduate Institute for Policy Studies. Tokyo, Japan.

[29] IFC (International Finance Corporation) (2000) Paths out of poverty: The role of private enterprise in developing countries, http:// www.ifc.org/publications/path_out_of_poverty.pdf

[30] Kalu, C.U. \& Imoagwu, C.P (2020f) Household Income as an indicator for addressing poverty,

[31] in: Encyclopedia of the UN Sustainable Development Goals. No Poverty(eds.)

[32] Walter L. F. Amanda L.S., Pinar, G.O,Anabella, M.A, Luciano, L.B and Tony

[33] Wall. Springer Publications, Palgrave Macmillan.

[34] Kemeny, T.(2009/2010) Does foreign direct investment drive technological upgrading? World Development 38(11): 10-24

[35] Klein, M., Aaron, C., \& Hadjimichael, B.(2000) Foreign direct investment and poverty reduction. Policy Research Working Paper 2613, World Bank

[36] Household income as an indicator for addressing poverty. In: United Nations Encyclopedia of

[37] Kolstad, I \& Tondel, L. (2002) Social development and foreign direct investment in services. CMI Report, 11, Chr, Michelsen Institute, Bergen

[38] Kurtishi-Kastrati, S. (2013) The effects of foreign direct investment for host country's economy. European Journal of Interdisciplinary Studies 5(1): 2638

[39] Liargovas, P.G. \& Skandalis, K.S. (2012) Foreign direct investment and trade openness: the case of developing economies. Social Indicators Research, 106:323-331. 
[40] Meyer, K.E. \& Sinani, E(2009) When and where does foreign direct investment generate positive spillovers? A meta-analysis. Journal of International Business Studies, 40(7): 16-32

[41] Moughalu, K.C. (2013) Emerging Africa: How the Global Economy "Last Frontier" can Prosper and Matter. Nigeria, Bookcraft

[42] Noorbaksh, F., Paloni, A \& Youssef, A. (2001) Human capital and FDI inflow to developing countries: New empirical evidence. World Development 29: 1593-1610

[43] Ogunniyi, M.B. \& Igberi, C.O. (2014) The impact of foreign direct investment on poverty reduction in Nigeria. Journal of Economics and Sustainable Development, 5(14): 28-52

[44] Ogunleye, E.K. (2008). Exchange rate volatility and foreign direct investment inflows in selected sub-Saharan African countries, 1970-2005. $\mathrm{Ph} . \mathrm{D}$ thesis, University of Ibadan, Nigeria.

[45] Olatunji, L. \& Shahid, M.S. (2015) FDI and economic growth in Nigeria: a co-integration Analysis. Business and Economic Research (Macrothink Institute) 5(1):243-261.

[46] Oman, C. (2001) Policy competition for foreign direct investment: A study of competition among governments to attract FDI, OECD Development Centre, Paris

[47] Pesaran, H.M., Shin, Y. \& Smith, R.J (2001) Bounds testing approaches to the analysis of level relationships. Journal of Applied Econometrics 16(3): 289-326.

[48] Pesaran, M.H. \& Shin, Y. (1999) An autoregressive Distributed Lag Modelling Approach to co-integration analysis. Econometrics and Economic Theory in the 20th Century: The Ragnar Frisch Centennial Symposium, Strom, S.(ed.) Cambridge University Press.

[49] Qayyum, U \& Mahood, Z. (2013) Inter-linkage between foreign direct investment and foreign trade in Pakistan: Are the complements or substitute (No. 2013: 91) Pakistan Institute of Development Economics.

[50] Rafiq, S. \& Yun, L.H. (2017) An empirical investigation of the effect of FDI on foreign trade of Pakistan. Global Journal of Economics and Business 3(3): 301-311

[51] Rhee, Y. (1990) The catalyst model of development: Lessons from Bangladesh's success with garment export, World Development 18(2)
[52] Seins, L.T. (2009) FDI and Openness: Differences in response across countries, Chr. Michelsen Institute Working Paper.

[53] Singh, A., \& Gin, I. (2016) Impact of inflation rate on the inflow of foreign direct investment in India. Project Guru.

[54] Smarzynska, B. K. (2002) Does foreign direct investment increase the productivity of domestic forum? In search of Spillovers through backward linkages. Policy Research Working Paper No 29. The world Bank, Washington DC. http://dx.doi.org/10.1596/1813-9450-2923.

[55] Tsai, P.L \& Huang, C.H. (2007) Openness, growth and poverty: The case of Taiwan. World Development, 35: 1858-1871

[56] UNCTAD (1994) Transactional corporations, employment and workplace, New York, Geneva.

[57] UNCTAD (1999) World Investment Report: Foreign direct investment and the challenge of development, New York, Geneva.

[58] UNCTAD (2015) World investment report: Reforming international investment governance. United Nations Conference on Trade and Development(UNCTAD).

[59] Wheeler, D \& Mody, A. (1992) International investment location decisions: The case of US firms. Journal of International Economics, 33:57- 76

[60] World Bank(2000/2001) World Development Report: Attacking poverty, Washington, DC.

[61] Zhang, P. \& Li, R.(2007) Country differences of the relationship between foreign direct investment and trade(Chinese) . International Trade Issues 1 : 84-90

\section{AUTHORS}

First Author - Attamah, Nicholas, Ph.D., Department of Economics, Enugu State University of Science and Technology, Enugu, Nigeria, Email: numanick@esut.edu.ng

Second Author - Kalu Chris U. Ph.D., Department of Economics, Nnamdi Azikiwe University, Awka, Nigeria Email: cu.kalu@unizik.edu.ng 